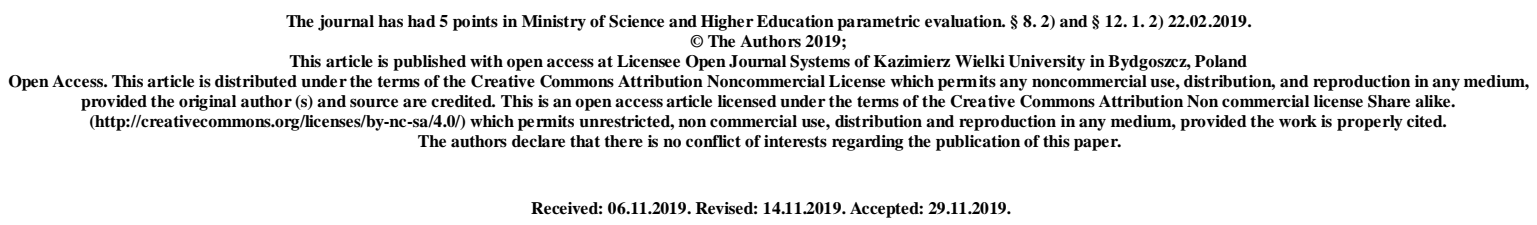

UDC: 616-008.82.46-07

\title{
INFLUENCE OF MAGNESIUM ON EXCITABILITY OF NEURONS OF DIFFERENT LEVELS OF THEIR ORGANIZATION
}

\author{
S. A. Antonenko
}

City Hospital No. 5 of Odessa

\begin{abstract}
The article indicates that the hyper-excitability of neurons is associated with ionic imbalance of cell membranes, in which a number of trace elements are involved. The energy component of these processes is associated with the presence of magnesium $(\mathrm{Mg})$ as a universal supplier of the latter. Mg supports the functioning of NMDA receptors, which does not allow the excitotoxic effects of glutamate, which triggers the mechanisms of Ca entry into the neuron and its death, to manifest itself. $\mathrm{Mg}$ stimulates the main excitatory neurotransmitter acetylcholine, regulates the release of serotonin, glycine, dopamine, thereby normalizing the extrapyramidal system, the spinal stem structures, and the final executive motor apparatus. Participates in the energy support of adaptation processes, the activation of central regulatory mechanisms, control the excess of catecholamines and corticosteroids, other hormones and mediators involved in stress reactions.
\end{abstract}

Keywords: magnesium; neuromuscular excitability; neurotransmission; stress 


\title{
ВЛИЯНИЯ МАГНИЯ НА ВОЗБУДИМОСТЬ НЕЙРОНОВ РАЗЛИЧНЫХ УРОВНЕЙ ИХ ОРГАНИЗАЦИИ
}

\author{
С. А. Антоненко
}

\section{Городская больница № 5 г. Одессы}

В статье указывается, что гипервозбудимость нейронов связана с ионным дисбалансом клеточных мембран, в котором участвует ряд микроэлементов. Энергетическая составляющая этих процессов связана с наличием магния $(\mathrm{Mg})$ как универсального поставщика последней. Mg поддерживает функционирование NMDAрецепторов, что не позволяет проявляться эксайтотоксическим эффектам глутамата, запускающего механизмы входа Са в нейрон и его гибели. $\mathrm{Mg}$ стимулирует работу основного возбуждающего нейротрансмиттера ацетилхолина, регулирует высвобождение серотонина, глицина, дофамина, тем самым нормализует работу экстрапирамидной системы, спинно-стволовых структур, конечного исполнительного двигательного аппарата. Участвует в энергетическом подкреплении адаптационных процессов, активации центральных регуляторных механизмов, контролируют избыток катехоламинов и кортикостероидов, других гормонов и медиаторов участвующих в стресс-реакциях.

\section{Ключевые слова: магний; нервно-мышечная возбудимость;} нейротрансмиссия; стресс

It is known that one of the mechanisms for the development of hyper-excitability of neurons is ionic imbalance, which disrupts the functioning of $\mathrm{Ca}$, as well as $\mathrm{Na}$, K-pumps, while up to $40 \%$ of the body's energy is consumed. Given the above, these processes are undoubtedly associated with the presence of a universal energy supplier - magnesium $(\mathrm{Mg})$ $[1,2]$.

An important factor of hyper-excitability is a decrease in the antagonistic balance of $\mathrm{Ca} 2+$ and $\mathrm{Mg} 2+[3]$, when with a lack of the latter there is no restriction of Ca entry into the cell, leading to a reduction in myofibrils. It can be argued that $\mathrm{Mg}$ is a "plug" in the ion channels that prevents $\mathrm{Ca}$ from entering the cell. At the same time, these two bioelements are "physiological partners" complementing each other in an optimal ratio of $2 \mathrm{Ca}: 1 \mathrm{Mg}$. [4]. A deficiency of both $\mathrm{Ca}$ and $\mathrm{Mg}$ causes convulsive muscle contractions [5]. 
It is known that the ratio of the concentration of extra- and intracellular $\mathrm{K}$ is the main factor determining the value of the membrane potential that affects the depolarization of the membranes of excitable cells and, as a result, hyperkalemia leads to hyper-excitability [6, 7].

Synergist $\mathrm{K}$ is $\mathrm{Mg}$ as the second major intracellular element. Deficiency of the latter leads to a deficiency of $\mathrm{K}$, while $\mathrm{Na}$ rushes into the cell, violating the osmotic pressure. Magnesium-dependent $\mathrm{Na}$, K-ATPase controls the intracellular concentration of substances by pumping $\mathrm{Na}$ from the cell [8].

$\mathrm{Na}$ as the basis of all intercellular fluids contributes to the value of the membrane potential. The concentration difference $\mathrm{Na}$ generates an electrical signal. An increase in the concentration of $\mathrm{Na}+$ increases the likelihood of the formation of an action potential due to a decrease in the membrane depolarization threshold, while alpha motor neurons are activated [9].

Deficiency of $\mathrm{Mg}$ and $\mathrm{Ca}$ increases the permeability of membranes for $\mathrm{Na}$, which can lead to a weakening of the phenomenon of "post-tetanic potentiation" in motor and insertion neurons, facilitating the conductivity of the pulse in the reflex arc. Polysynaptic discharges appear and reflex contractions increase in response to irritation. The electromechanical excitability of motor, sensory or autonomic conductors increases, which explains the manifestations of tetany, as well as impaired function of internal organs [10].

Transmission. A decrease in $\mathrm{Mg} 2+$ concentration disrupts the functioning of NMDA (glutamate) receptors as triggering the mechanism of $\mathrm{Ca}$ entry into the neuron and its death. Moreover, an insufficient amount of $\mathrm{Mg}$ cannot block all NMDA receptors for the exciting mediator of glutamate with its known excitotoxic effects [11].

$\mathrm{Mg}$ deficiency reduces the ability to inhibit the release of acetylcholine (ACh) from storage granules, which is involved in all processes of neuromuscular excitation of striated muscles. The magnesium-dependent decrease in cholinesterase activity also contributes to this. At the same time, it is known that smooth muscles are highly sensitive to ACh, which has an opposite effect on norepinephrine (NA) on its membrane potential, decreasing its value and increasing the frequency of spontaneous action potentials with an increase in tone. Membrane depolarization due to the action of ACh increases its permeability to $\mathrm{Na}+$ and $\mathrm{Ca}+$ [12]. Another characteristic feature of smooth muscle is the presence of receptor proteins capable of triggering or inhibiting the magnesium-dependent contractile process.

In most vegetative fibers that innervate smooth muscle, they diffusely branch and, without coming into contact with the membranes, form diffuse compounds with secretion of the mediator into the matrix. The mediators of these processes are ACh and NA. ACh can 
excite or inhibit smooth muscle contraction of various organs. HA - inhibits by binding first to various receptor proteins, while the type of receptor determines how ACh and HA will behave $[12,13]$.

Excitation and contractility of smooth muscles also depend on controlled $\mathrm{Mg}$ release of histamine from mast cells. The latter, like serotonin, can affect myocytes, increasing the concentration of intracellular $\mathrm{Ca}[14]$.

Hyperactivity of alpha and gamma motor neurons in violation of the inhibitory benefits of GABAergic effects easily occurs with a deficiency of $\mathrm{Mg}$.

The increased activity of the neurons of the anterior horn can be mediated by blocking the receptors of the inhibitory neurotransmitter glycine and its release into the synaptic cleft of Renshaw cells of the spinal cord. Moreover, the mediating ability of glycine cannot be fully manifested in conditions of $\mathrm{Mg}$ deficiency $[15,16]$.

$\mathrm{Mg}$ also regulates the secretion of parathyroid hormone, a decrease in the content of which leads to a violation of the utilization of $\mathrm{Ca}$ and its mobilization from bone. The resulting hyperphosphatemia due to reabsorption of phosphorus further reduces the concentration of $\mathrm{Ca}$ in the blood. Such a possible variant of the development of idiopathic tetany necessarily proceeds against the background of hypomagnesemia [13].

Extrapyramidal system. Neurons of the basal ganglia participate in integrative processes of motor activity, in particular, the caudate nucleus, having wide connections with the central nervous system structures and various mediator inputs, inhibits the functioning of Glomus pallidum, the irritation of which causes motor reactions, contraction of the extremities, tremor, myoclonia. The caudate nucleus has projections and is connected through the reticulo-spinal cord with high-frequency gamma-neurons and the final executive motor apparatus, as well as with the complex reflex center of the brain stem and other subcortical nodes $[5,17]$.

Gamma-motor neurons are under constant inhibitory control by the red nuclei (normal). In case of loss of control, tonic excited and performing anti-gravity functions of the cell are excited and disinhibited, first of all, which can manifest itself in the form of decerebral rigidity [18].

With dopamine deficiency, Glomus pallidum can also disinhibition with activation of the spinal stem systems with subsequent characteristic motor disorders, increased rigidity, tremor, etc.

A lack of $\mathrm{Mg}$ leads to a deficiency of dopamine, the main neurotransmitter, which reduces the effects of stimulating neuromuscular mediators [8]. 
Stress. The hyper-excitability of the neuro-muscular apparatus is a consequence of the stress situation. The autonomic nervous system (ANS) receives information and poisons it through the autonomic vehicles to the response organs. In this case, the ACh works as a universal mediator, incl. stimulates skeletal muscles (with activation of $\mathrm{Na}$ channels of myocyte membranes, which contributes to the stimulation of Ca-channels), as well as in the central nervous system, including the hippocampus, whose activity is aimed at adaptation to stress-induced reactions [19]. $\mathrm{Mg}$ inhibits the release of $\mathrm{AH}$ from the synapses of neuromuscular conductors, thereby controlling the body's functions under stress. In addition, the synthesis of constituents of ACh (phospholipid - choline and Acetyl CoA) occurs with the participation of $\mathrm{Mg}$, the lack of which does not allow to fully realize the energy reinforcement of adaptation processes together with Acetyl CoA. In addition, $\mathrm{Mg}$ enhances ACh degradation by activation of cholinesterase $[12,20]$.

The release of adrenaline prepares the body for danger, strenuous activity during stress with hyperconstriction of smooth muscles, i.e. angiospasm, stimulation of cardiovascular activity. It should take into account the antagonistic interaction of the hormone and $\mathrm{Mg}$, which, if necessary, can control the excess of adrenaline [2].

NMDA receptors are excited under any stress, passing $\mathrm{Ca} 2+$ into the cell against a background of significant loss of $\mathrm{Mg}$, disrupting bioenergetic homeostasis with a decrease in ATP synthesis, impaired respiratory chain and an increase in the number of free radicals, damage to membranes, and cell death [21]. Under stress against the background of $\mathrm{Mg}$ deficiency, the work of transporters that remove the glutamate NMDA receptor activator from the extracellular space is disrupted [22]. In such cases, NMDA-mediated hyperactivation of neurons, especially the hippocampus (given its wide connections with all parts of the central nervous system) can form a generator of pathological excitation in the brain [23, 24, 25].

One of the important mechanisms of adaptation to stressful situations is the activation of central regulatory mechanisms, which under the influence of stimuli inhibit the release of catecholamines (CA) and corticosteroids. Neurons synthesize and secrete GABA, dopamine, serotonin, glycine, peptides that interact with stress-implementing systems and modulate their activity (limit stress response and adaptation) [26].

At the periphery, no less important regulatory systems of adenine nucleotides, prostaglandins, antioxidant - act as modulators that can limit the effects of catecholamines and other factors (the basis of desentitization and prevention of damage) [2, 3, 4]. Mg is actively involved and regulates the stress-realizing adrenergic system, stress-limiting: serotonin-, 
dopaminergic systems. It also affects the neuropeptides that inhibit the action of the stress system and a number of hormones providing an adequate response to the stressor [27, 28].

$\mathrm{Mg}$ affects the activity of phospholipase (participating in the synthesis of arachidonic acid in the bilipid layer of the membrane), at the same time, prostaglandin synthetase and prostaglandins are activated, which block the excretion of CA from nerve endings by a feedback mechanism, and prostacyclin reduces the effects of the CA in target organs [20, 30, $31]$.

At the spinal level, conjugated relationships of motor neurons are provided by the inserted nerve cells. Gamma motor neurons are coactivated upon stimulation of alpha motor neurons. This leads to a reduction in extra- and infrasional muscle fibers. Presynaptic inhibition of alpha and gamma motor neurons is provided by neurons of the GABAergic system, where $\mathrm{Mg}$ acts as a harmonizer and activator of their functioning [26, 32].

At the neural level, the well-known hypothesis of muscle spasms is based on changes in the functioning of proprioreceptors and increased afferent activity of the muscle spindle, which violates the control system for alpha motor neurons (the mechanism for inhibiting muscle contraction in response to physical activity does not work). According to the theory of electrolyte seizures, muscle cramps occur with ionic imbalance in cases of $\mathrm{Na}$ deficiency, changes in the ratio of major ions, which leads to hyper-excitability of neuromuscular synapses [33]. It should take into account the contribution of the central nervous system to enhancing the excitability of a neuron, the implementation of reciprocal muscle relationships [34], the distribution of excitation to motor neurons of the front horns [35], as well as the suprasegmental divisions of the ANS, which directly and indirectly change the excitability of neurons at various levels of the nervous system [36].

Based on the above, it can be stated that $\mathrm{Mg}$ is a systemic substance that is actively involved in the mechanisms of neuromuscular excitability; activates and controls ion balance, depolarization and homeostasis of minerals in relation to the membrane of neurons and excitable cells; regulates the synthesis and effectiveness (including energy) of neurotransmitters, neuropeptides, hormones, as well as the active component of all structures of the nervous system involved in the processes of neuromuscular excitation. Magnesium protects the body from hyperactivation of neurons due to stress reactions and stimulates the processes of adequate adaptation. 


\section{References}

1. Gunther $\mathrm{T}$. The biochemical function of $\mathrm{Mg} 2+$ in insulin secretion, insulin signal transduction and insulin resistance // Magnes. Res. 2010. № 23 (1). P. 5-18.

2. Gromova O.A. Defitsit magniya kak problema stressa i dezadaptatsii u detey / O.A.Gromova, I.Yu.Torshin, T.R.Grishina, L.E. Fedotova // RMZh. 2012. \#16. S. 813.

3. Mazur A., Maier J. A., Rock E. et al. Magnesium and the inflammatory response: potential physiopathological implications // Arch Biochem Biophys. 2007; 458 (1): 48-56.

4. Gromova O.A. Neyrotroficheskaya sistema mozga: neyropeptidyi, makro- i mikroelementyi, neyrotroficheskie preparatyi. Lektsiya / O.A.Gromova // Mezhdunarodnyiy nevrologicheskiy zhurnal 2(12) 2007 - S. 34-38.

5. Uholkina G.B. Rol magniya v zabolevaniyah serdechno-sosudistoy sistemyi / G.B.Uholkina // RMZh, \# 7. - 2011. - S. 476.

6. Anesteziologiya. Kak izbezhat oshibok: Sb. - Pod red. K.Markuchcha, N.A.Koena i dr., M.: GETAR-Media, 2011

7. Gromova O.A. Magnievyie taynyi biblioteki Kohrana: sovremennyiy vzglyad na problemu / O.A.Gromova, E.Yu.Lisitsina, I.Yu.Torshin, O.N.Gracheva // Rossiyskiy Vestnik akushera-ginekologa, - \# 5, 2011. - S. 20-27

8. Sokolova L.I. Zastosuvannya sulfatu magniyu pri Ishemichnomu insulti / L.I.Sokolova / / Ukrayinskiy nevrologichniy zhurnal, 2015. - \# 4. - S. 91-97.

9. Ajeena I.M. (ed.) Advances in Clinical Neurophysiology Rieka: InTech, 2012. $202 \mathrm{p}$.

10. Suponeva N.A. Myishechnyie krampi: voprosyi patogeneza, differentsialnoy diagnostiki i lecheniya / N.A.Suponeva, I.V.Borodulina // RMZh. 2015. \#24. S. 1463-1466.

11. Yakimovskiy A.F., Varshavskaya V.M., Yakubenko A.L. Vnutristriarnoe vvedenie magniya posle pikrotoksina ne snizhaet dvigatelnuyu giperaktivnost u kryis. // Byul.eksperim.biologii i meditsinyi 2008; T.146, N8 - S. 128-13.

12. Fiziologiya cheloveka pod red. V.M.Pokrovskogo, G.F.Korotko- 2-e izd., pererab. i dop. - M.: 2003. -656 s.

13. Illarioshkin S.N. Nedostatochnost magniya: nekotoryie nevrologicheskie aspektyi i puti korrektsii / S.N.Illarioshkin / Nervnyie bolezni. - \#1, 2005. - S. 38-40

14. Korpachev V.V. Metabolicheskie effektyi i klinicheskoe primenenie magniya orotata / V.V.Korpachev, N.M.Gurina // Mezhdunarodnyiy endokrinologicheskiy zhurnal. \#2, 2007. - S. 23-28. 
15. Torshin I.Yu. Molekulyarnyie roli magniya i piridoksina $\mathrm{v}$ antialkogolnoy zaschite organizma / I.Yu.Torshin, E.Yu.Egorova // Vrach, 2010. - \# 7. - S. 51-54.

16. Tsirkin V.I. Rol gistamina v reproduktsii / V.I.Tsirkin, S.V. Hlyibova // Vyatskiy meditsinskiy vestnik, \# 3-4, 2006. - S. 62-68.

17. Serov V.N. Ispolzovanie tsitrata magniya dlya profilaktiki prezhdevremennyih rodov u beremennyih s vyisokim riskom nevyinashivaniya / V.N.Serov, N.K. Tetruashvili. O.A.Gromova // RMZh, \#17, 2012. - S. 846.

18. John A. Kiernan. Barr's the Human Nervous System: An Anatomical Viewpoint. 8th. - Hagerstown, MD: Lippincott Williams \& Wilkins, 2005.

19. Vetrile L.A. Vliyaniya antitel $\mathrm{k}$ glutamatu pri intranazalnom vvedenii na soderzhanie vozbuzhdayuschih i tormoznyih aminokislot $\mathrm{v}$ gippokampe i gipotalamuse kryis pri kombinirovannom stressornom vozdeystvii / L.A.Vetrile, I.A.Zaharova, V.S.Kudrin, P.M.Klodt // Patologicheskaya fiziologiya i eksperimentalnaya terapiya, 2016.-N 1.-S.4-10.

20. Kadyikov A.S.Magniy glazami nevrologa / A.S.Kadyikov, S.N.Busheneva // Zhurnal "Nervyi", 2006, \#1. - S. 23-25

21. Karkashadze G.A. Defitsit magniya v detskoy nevrologii: chto nuzhno znat pediatru? / G.A.Karkashadze, L.S.Namazova-Baranova // Voprosyi sovremennoy pediatrii 2014; 13 (5): 17-25.

22. Danbolt N.C.Glutamat euptake // Prog. Neurobiol. 2001. V.65. N1. P. 1-105.

23. Kryizhanovskiy G. N. Osnovyi obschey patofiziologii. - M.: MIA, 2011. - 253 s.

24. Ryan M.F., Babrour H. Magnesium measurement in routine clinical practice // Ann Clin Biochem., 1998 Jul;35 (Pt 4):449-59.

25. Ianello S. Belfore P. Hypomagnesemia. A review of pathophysiological, clinical and therapeutical aspects. - Panminerva Med. 2001 Sep;43 (3):177-209.

26. Kuznetsov V.V. Sovremennoe predstavlenie o roli GAMK v korrektsii neyrokardialnoy patologii / V.V.Kuznetsov, M.S.Egorova // Novosti meditsinyi i farmatsii. \# 11 (544) - 2015 - S. 4.

27. Budanov M.V. Klinicheskie proyavleniya i effektyi korrektsii defitsita magniya $\mathrm{u}$ detey / Budanova M.V., Aslanova P.A., Budanov P.V. // Trudnyiy patsient. - 2009. - \# 1-2. S. 17-22.

28. Sartori S.B., Whittle Magnesium deficiency induces anxiety and HPA axis dysregulation: modulation by therapeutic drug treatment. - Neuropharmacology. 2012 Jan;62 (1) :304-12. doi: 10.1016/ j.neuropharm. 2011.07.027. Epub 2011.

29. Langeslag M., Clark K., Moolenaar W.H., 2007; Xing J., Strange K., 2009]. 
30. Fofanova I.Yu. Defitsit magniya i ego svyaz s akusherskoy patologiey /I.Yu.Fofanova // Meditsinskiy sovet" \#5. - 2014. - S. 23-27

31. Rayssiguier Y, Mazur A. Magnesium and inflammation: lessons from animal models. Clin Calcium 2005;15(2):245-8

32. Yafarova G. G., Baltina T. V., Pleschinskiy I. N. Funktsionalnoe sostoyanie dvigatelnyih tsentrov spinnogo mozga $\mathrm{v}$ usloviyah ego travmaticheskogo povrezhdeniya / G. G. Yafarova, T. V. Baltina, I. N. Pleschinskiy. - Nizhnekamsk: Izd-vo NF MGEI. - 2008. $74 \mathrm{~s}$.

33. Bergeron M.F. Muscle Cramps during Exercise - Is It Fatigue or Electrolyte Deficit?// Current Sports Medicine Reports: doi: 10.1249/JSR.0b013e31817f476a.

34. Minetto M.A., Holobar A., Botter, Farina D. Origin and development of muscle cramps // Exerc Sport Sci Rev., 2013. vol. 41, N1.PP.3-10.

35. Obi T, Mizoguchi K, Matsuoka H, Takatsu M, and Nishimura Y: Muscle cramp as the result of impaired GABA function - an electrophysiological and pharmacological observation. Muscle Nerve 16:1228-1231, 1993.

36. Phisiology : Nextbook / Edited by V. Moroz, O.Shandra. - Vinnitsa : Nova Knyha Publishers, 2011. -888 pp. 